\title{
PENGARUH ARAH POSISI PEMASANGAN PANEL SURYA TERHADAP OUTPUT DAYA KELUARAN
}

\author{
Yusrijal Shalih ${ }^{1}$, Suratno ${ }^{2}$ \\ ${ }^{1,2)}$ Prodi D4 Teknik Listrik, Politeknik Negeri Samarinda \\ ${ }^{1)}$ rizalshalih@gmail.com, ${ }^{2)}$ suratnopolnes@gmail.com
}

\begin{abstract}
Abstrak - Kebutuhan energi yang tambah tahun semakin meningkat merupakan salah satu permasalahan dan tantangan dimasa ini. Maka dari itu saat ini banyak modul modul solar sel yang dapat menyerap energi matahari dan merubahnya menjadi sumber listrik atau energi yang dapat digunakan dalam kehidupan sehari hari. Tujuan penelitian ini adalah untuk mengetahui pengaruh arah posisi pemasangan panel surya terhadap daya keluaran panel surya dan mengetahui pengaruh arah posisi pemasangan panel surya terhadap tegangan dan arus. Dengan melakukan analisis maka Efisiensi arah posisi pemasangan panel surya menghadap timur sebesar $11.6 \%$ dan efisiensi arah posisi pemasangan panel surya menghadap selatan sebesar 3.6\% dan efisensi arah posisi pemasangan panel surya mengahadap utara sebesar $10.85 \%$.
\end{abstract}

Kata Kunci : Panel Surya, Daya Keluaran

\section{Pendahuluan}

Masyarakat dunia saat ini telah berlomba memanfaatkan energi baru terbarukan sebagai sumber energi untuk kehidupan. Pemerintah telah merencanakan target energi baru terbarukan. peralihan sumber energi energi baru terbarukan ini diyakini sebagai solusi jitu menjawab tantangan global [1].

Dalam memenuhi kebutuhan energi yang semakin meningkat dan juga untuk mengembangkan teknologi energi baru terbarukan maka penelitian ini mengambil sumber energi terbarukan melalui surya yang berasal dari matahari.

Indonesia sebagai negara yang terletak di kawasan khatulistiwa, memiliki potensi energi matahari yang melimpah. Dengan matahari yang bersinar sepanjang tahun, lembaga penerbangan dan antariksa nasional mencatat radiasi harian rata-rata energi matahari adalah 4.8 KWh/m2 [3].

Dengan potensinya yang sangat besar tersebut, energi matahari dapat menjadi sumber energi utama di masa depan. Apalagi dengan beberapa keunggulan seperti, energi matahari merupakan sumber energi yang hampir tak terbatas dan ramah lingkungan.

Maka dari itu saat ini banyak dibangun modulmodul solar sel yang dapat menyerap energi matahari dan merubahnya menjadi sumber listrik atau energi yang dapat digunakan dalam kehidupan sehari-hari.

Maka untuk menghindari terjadinya kesalahan yang berakibat pada kerja penyerapan sinar matahari tidak optimal, cara pemasangan yang benar pada unit panel surya yang menjadi komponen utama pembangkit listrik tenaga surya perlu menjadi perhatian. Tepatnya adalah pada arah dan kemiringan dari panel surya

menjadi bagian utama sebagai penangkap atau penyerap sinar matahari.

penelitian yang dilakukan dalam penelitian [8] Pengaruh perubahan intensitas matahari terhadap daya keluaran panel surya sangat dipengaruhi oleh intensitas cahaya matahari yang diterima oleh sistem.

penelitian yang dilakukan dalam penelitian [4] bahwa masalah sistem panel surya yang masih rendah tingkat efisiensinya dan masih sedikit penerapannya di masyarakat sebagai alternatif sumber energi listrik terbarukan.

Dan di dalam penelitian yang dilakukan dalam penelitian [5] bahwa dalam mempertahankan sinar matahari jatuh ke sebuah permukaan panel sel surya secara tegak lurus akan mendapatkan energi maksimum $\pm 1000 \mathrm{~W} / \mathrm{m} 2$ atau $1 \mathrm{~kW} / \mathrm{m} 2$. Kalau tidak dapat mempertahankan ketegak lurusan antara sinar matahari dengan bidang sel surya, maka ekstra luasan bidang panel surya dibutuhkan dalam posisi letak sel surya terhadap matahari.

\section{LANDASAN TEORI \\ A. Sel Surya (Solar Cell)}

Solar cell atau sel surya atau sel fotovoltaik merupakan alat yang mengubah energi sinar matahari menjadi listrik. Sebenarnya fotovoltaik (photovoltaik) merupakan istilah yang dipergunakan untuk teknologi dan riset yang berkaitan dengan aplikasi sel fotovoltaik tersebut untuk menghasilkan kelistrikan dari sinar atau cahaya, di mana sinar tersebut tidak hanya terbatas pada sinar matahari saja [15].

Sel surya adalah perangkat listrik solid-state (p-n junction) yang mengubah energi cahaya langsung menjadi listrik (dc) menggunakan efek fotovoltaik. Proses konversi pertama membutuhkan bahan yang menyerap energi matahari (foton), dan kemudian 
meningkatkan elektron ke keadaan energi yang lebih tinggi, dan kemudian aliran elektron berenergi tinggi ini ke sirkuit eksternal [6], silikon adalah salah satu bahan yang menggunakan proses tersebut.

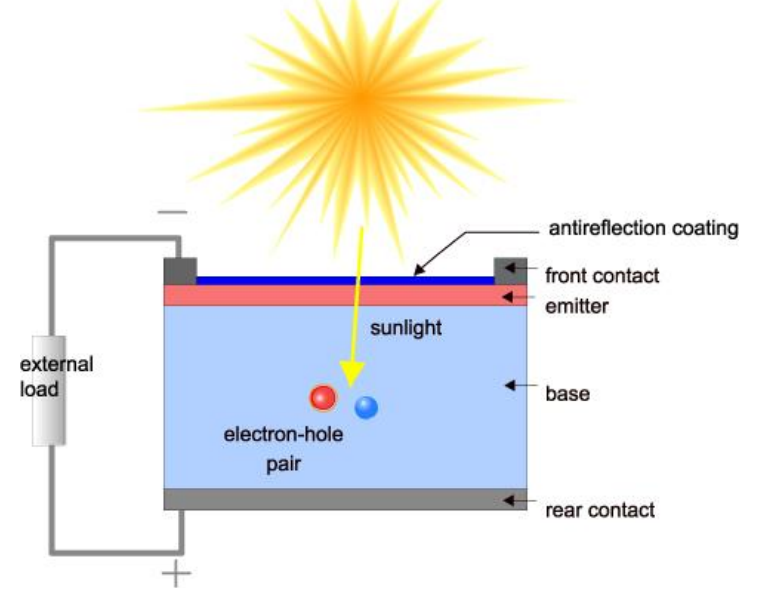

Gambar 1 Struktur Solar Cell

\section{B. Modul Panel Surya}

Panel surya merupakan alat utama yang memiliki peran sangat penting dalam pembangkit listrik tenaga surya. Panel surya berfungsi untuk mengubah energi surya (matahari) menjadi energi listrik. Dalam sebuah panel surya terdapat rangkaian sel surya yang dihubungkan secara seri atau parallel. Sel surya ini yang akan menerima cahaya matahari dan merubahnya menjadi sumber energi listrik [7].

Cara kerja panel surya yaitu mengkonversi lansung cahaya menjadi listrik pada tingkat atom yang mana beberapa bahan menunjukkan sifat yang dikenal sebagai efek fotolistrik yang menyebabkannya menyerap foton cahaya dan melepaskan elektron. Ketika elektron bebas ini ditangkap, hasil arus listrik yang dapat digunakan sebagai listrik.

\section{Arah Hadap Panel Surya}

Rangkaian panel surya harus dipasang dengan sudut kemiringan dan sudut azimut yang tepat, yaitu arah kompas dari arah datangnya sinar matahari. Arah hadap panel surya sangat menentukan jumlah keluaran yang cukup dari pembangkit listrik. Idealnya, arah hadap panel surya harus diatur tegak lurus dengan sinar matahari untuk menerima radiasi secara langsung [18].

\section{Metodologi Penelitian}

\section{A. Alat Dan Bahan}

a. Panel fotovoltaik model ST-Solar 20Wp

Polycrystaline

b. Multimeter digital merk krisbow tipe KW06-271.

c. Luxmeter digital merk smart sensor tipe AS803.

\section{B. Gambaran Umum Sistem}

Metode penelitian meliputi: pengujian sistem panel surya, pengujian pengaruh arah posisi pemasangan panel surya terhadap daya keluaran, pengambilan data serta analisa data.

Pada penelitian ini akan diambil data keluaran panel surya type polycrystalline dengan penetapan tetap pada sudut panel sebesar $5^{\circ}$. Data keluaran panel surya tersebut akan diambil berdasarkan arah posisi pemasangan panel surya yaitu arah timur, arah utara, dan arah selatan. Keluaran panel surya tersebut akan diukur dalam bentuk tegangan dan arus, kemudian data tersebut akan dihitung dalam bentuk energi yang kemudian dibandingkan.

Pengukuran yang dilakukan dengan menetapkan sudut kemiringan $5^{\circ}$. Hal ini disebabkan adanya jalur khatulistiwa yang melewati sehingga penetapan sudut kemiringan yang terbaik adalah dalam skala $5^{\circ}$ sampai dengan $15^{\circ}[14]$.
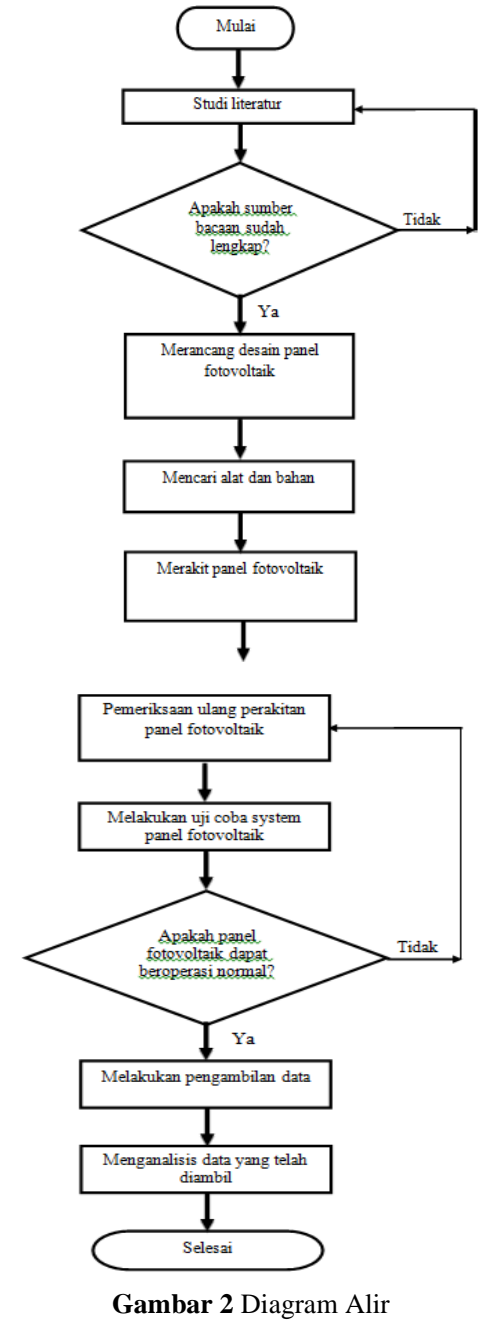

IV. HASIL DAN PEMBAHASAN

A. Hasil Percobaan Panel Surya fotovoltaik 
Penelitian ini merupakan salah satu langkah untuk mengetahui hubungan intensitas cahaya matahari yang mampu dikonversi oleh sel surya menjadi energi listrik serta kapan energi tertinggi yang dapat dihasilkan oleh panel surya type Polycrystaline. Untuk melakukan pengambilan data panel fotovoltaik digunakan metode penelitian dengan cara meletakkan luxmeter sejajar dengan panel surya, voltmeter dan amperemeter dipasang parallel dengan panel surya. pengukuran yang dilakukan dalam tiga hari dengan jarak waktu per satu jam selama 9 jam pengambilan data.

Tabel 1 Data pengukuran panel fotovoltaik arah posisi timur

\begin{tabular}{|r|c|c|c|c|}
\hline \multicolumn{1}{l|}{ No } & Waktu & $\begin{array}{l}\text { Intensitas } \\
\text { Cahaya } \\
\text { Matahari } \\
\text { (Lux) }\end{array}$ & $\begin{array}{c}\text { Tegangan } \\
\text { (V) }\end{array}$ & $\begin{array}{c}\text { Arus } \\
\text { (A) }\end{array}$ \\
\hline 1 & 08.30 & 28050 & 19,85 & 0,477 \\
\hline 2 & 09.30 & 93000 & 19,93 & 1,098 \\
\hline 3 & 10.30 & 595300 & 19,94 & 1,194 \\
\hline 4 & 11.30 & 124000 & 19,77 & 1,340 \\
\hline 5 & 12.30 & 125000 & 19,61 & 1,309 \\
\hline 6 & 13.30 & 17140 & 19,24 & 0,286 \\
\hline 7 & 14.30 & 4325 & 17,34 & 0,053 \\
\hline 8 & 15.30 & 1904 & 17,03 & 0,023 \\
\hline 9 & 16.30 & 2088 & 17,77 & 0,035 \\
\hline
\end{tabular}

Tabel 2 Data pengukuran panel fotovoltaik arah posisi selatan

\begin{tabular}{|c|c|c|c|c|}
\hline No & Waktu & $\begin{array}{c}\text { Intensitas } \\
\text { Cahaya } \\
\text { Matahari } \\
\text { (Lux) }\end{array}$ & $\begin{array}{c}\text { Tegangan } \\
\text { (V) }\end{array}$ & $\begin{array}{c}\text { Arus } \\
\text { (A) }\end{array}$ \\
\hline 1 & 08.30 & 36480 & 19,77 & 0,33 \\
\hline 2 & 09.30 & 32690 & 20,00 & 0,36 \\
\hline 3 & 10.30 & 19200 & 19,80 & 0,28 \\
\hline 4 & 11.30 & 17090 & 19,69 & 0,17 \\
\hline 5 & 12.30 & 24120 & 19,70 & 0,23 \\
\hline 6 & 13.30 & 36670 & 20,00 & 0,38 \\
\hline 7 & 14.30 & 43700 & 20,2 & 0,41 \\
\hline 8 & 15.30 & 11100 & 19,44 & 0,28 \\
\hline 9 & 16.30 & 20790 & 19,85 & 0,30 \\
\hline
\end{tabular}

Tabel 3 Data pengukuran panel fotovoltaik arah posisi utara

\begin{tabular}{|c|c|c|c|c|}
\hline No & Waktu & $\begin{array}{c}\text { Intensitas cahaya } \\
\text { Matahari } \\
\text { (Lux) }\end{array}$ & $\begin{array}{c}\text { Tegangan } \\
\text { (V) }\end{array}$ & $\begin{array}{c}\text { Arus } \\
\text { (A) }\end{array}$ \\
\hline 1 & 08.30 & 30960 & 19,90 & 0,30 \\
\hline 2 & 09.30 & 33060 & 20,1 & 0,35 \\
\hline 3 & 10.30 & 19060 & 19,77 & 0,19 \\
\hline 4 & 11.30 & 170400 & 19,74 & 1,18 \\
\hline 5 & 12.30 & 244900 & 19,70 & 1,25 \\
\hline 6 & 13.30 & 37930 & 19,88 & 0,39 \\
\hline 7 & 14.30 & 42900 & 19,45 & 0,40 \\
\hline 8 & 15.30 & 8805 & 19,40 & 0,13 \\
\hline 9 & 16.30 & 21130 & 19,95 & 0,32 \\
\hline
\end{tabular}

\section{B. Hasil Pengukuran Intensitas Cahaya Matahari}

Hasil intensitas cahaya matahari yang telah dihasilkan oleh luxmeter.
Tabel 4 Hasil Pengelompokan Pengukuran Intensitas cahaya matahari (Lux)

\begin{tabular}{|c|l|l|l|}
\hline \multirow{3}{*}{ Jam } & \multicolumn{3}{|c|}{ Pengukuran Intensitas Cahaya Matahari } \\
\cline { 2 - 4 } & Arah timur & Arah selatan & Arah utara \\
\hline 08.30 & 28050 & 36480 & 30960 \\
\hline 09.30 & 93000 & 32690 & 33060 \\
\hline 10.30 & 595300 & 19200 & 19060 \\
\hline 11.30 & 124000 & 17090 & 170400 \\
\hline 12.30 & 125000 & 24120 & 244900 \\
\hline 13.30 & 17140 & 36670 & 37930 \\
\hline 14.30 & 4325 & 43700 & 42900 \\
\hline 15.30 & 1904 & 11100 & 8805 \\
\hline 16.30 & 2088 & 20790 & 21130 \\
\hline Rata-rata & 110089,6667 & 26871,11111 & 67682,77778 \\
\hline & & & \\
\hline
\end{tabular}

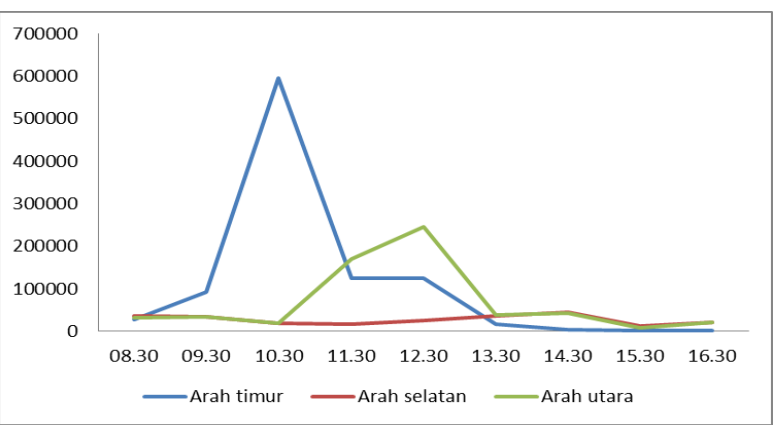

Gambar 3 Grafik intensitas cahaya matahari

Grafik intensitas cahaya matahari pada gambar 3 dapat dilihat bahwa penyinaran intensitas cahaya terbaik terjadi pada saat arah posisi pemasangan panel surya berada pada arah timur dan utara. Dibuktikan kekuatan penyinaran tertinggi terjadi pada pukul 10.30 pada posisi pemasangan panel surya ke arah timur yaitu sebesar 595300 lux. Pada posisi pemasangan panel surya arah utara penyinaran intensitas cahaya matahari tertinggi pada pukul 12.30 yaitu sebesar 244900 lux. Pada posisi pemasangan panel surya pada arah selatan panel surya hanya menyerap intensitas cahaya matahari tidak sebesar yang terjadi pada posisi pemasangan arah timur dan arah utara.

perbandingan intensitas cahaya matahari terhadap arah posisi pemasangan pada panel surya. Data tersebut diambil berdasarkan hasil rata rata intensitas cahaya matahari yang menyinari panel surya berdasarkan arah posisi pemasangan panel surya. Rata-rata intensitas cahaya matahari pada arah timur sangat besar yaitu 110089,6667 lux. Rata-rata intensitas cahaya matahari pada arah utara juga besar yaitu 67682,778 lux tetapi tidak sebesar arah posisi pemasangan menghadap timur. Tetapi tidak dengan intensitas cahaya matahari pada arah posisi pemasangan panel surya menghadap selatan yang hanya mendapatkan intensitas cahaya matahari rata-rata sebesar 26871,11 lux. Hal ini disebabkan arah 
posisi pemasangan panel surya yang mengikuti pola penyinaran matahari dan faktor cuaca juga menjadi salah satu faktor dari besar dan kecilnya intensitas cahaya matahari yang diterima panel surya.

\section{Hasil Perhitungan Daya Keluaran Panel fotovoltaik}

Dengan rumus yang sama akan didapat perhitungan daya selama pengujian.

$$
\begin{aligned}
\text { Pout } & =\text { Vout } \times \text { Isc } \\
& =(19,94) \times(1,194) \\
& =23,80836 \text { Watt }
\end{aligned}
$$

Tabel 5 Hasil perhitungan daya keluar panel surya

\begin{tabular}{|r|r|r|r|}
\hline \multirow{2}{*}{ Jam } & \multicolumn{3}{|c|}{ DAYA (Watt) } \\
\cline { 2 - 4 } & Arah timur & Arah selatan & Arah utara \\
\hline 08.30 & 9,468 & 6,524 & 5,970 \\
\hline 09.30 & 21,883 & 7,200 & 7,035 \\
\hline 10.30 & 23,808 & 5,544 & 3,756 \\
\hline 11.30 & 26,492 & 3,347 & 23,293 \\
\hline 12.30 & 25,669 & 4,531 & 24,625 \\
\hline 13.30 & 5,503 & 7,600 & 7,753 \\
\hline 14.30 & 0,919 & 8,282 & 7,780 \\
\hline 15.30 & 0,392 & 5,443 & 2,522 \\
\hline 16.30 & 0,622 & 5,955 & 6,384 \\
\hline Rata-rata & 12,751 & 6,047 & 9,902 \\
\hline & & & \\
\hline
\end{tabular}

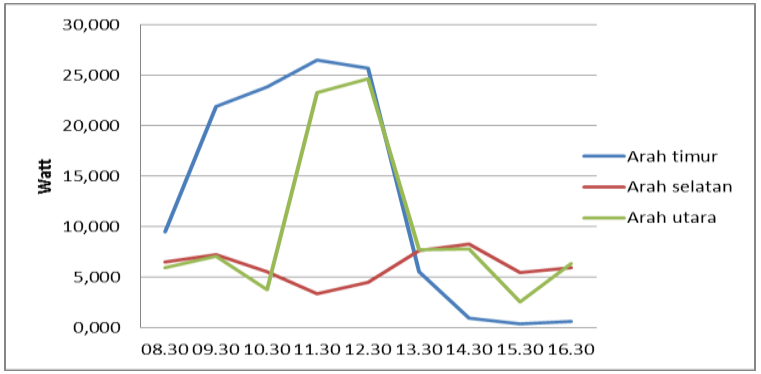

Gambar 4 Grafik perhitungan daya

Perhitungan daya pada Tabel 5 menandakan lajur daya yang dihasilkan oleh panel surya rata rata hampir semua menunjukkan nilai daya maksimum panel surya terjadi pada pukul 10.30 sampai dengan pukul 13.30 Wita waktu setempat yaitu menunjukkan daya dengan kisaran besaran 20 watt sampai 25 watt kecuali pada arah posisi pemasangan panel surya pada arah selatan.

Jadi dapat diketahui bahwa kinerja panel surya dapat bekerja maksimun pada pukul 10.30 sampai 12.30. Hal ini juga perlu diingat bahwa faktor cuaca juga bisa menentukan kinerja panel surya untuk menghasilkan daya keluaran yang baik atau buruk.
Untuk mengetahui bagaimana pengaruh arah posisi pemasangan panel surya terhadap daya keluaran maka dapat dilihat pada gambar 5 grafik perbandingan daya keluaran panel surya.

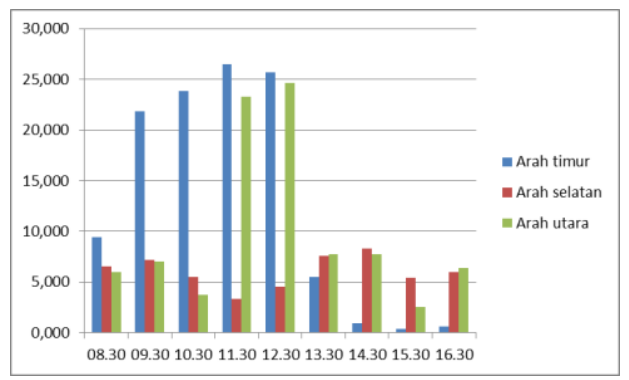

Gambar 5 grafik perbandingan daya keluaran panel surya

\section{Perubahan Intensitas Cahaya Matahari Terhadap Daya Keluaran}

Untuk mengetahui bagaimana pengaruh arah posisi pemasangan panel surya terhadap daya keluaran maka dapat dilihat pada gambar 5 grafik perbandingan daya keluaran panel surya. maka dapat di simpulkan bahwa perubahan intensitas cahaya matahari berpengaruh terhadap daya keluaran panel surya yaitu semakin besar intensitas cahaya matahari yang ditimbulkan maka semakin besar pula daya keluaran yang dapat dihasilkan oleh panel surya. Dan posisi pemasangan panel surya berpengaruh terdahap daya dan intensitas cahaya matahari yang di timbulkan.

\section{F. Efisiensi Panel Surya}

Efisiensi yang dihitung bersdasarkan nilai energi daya tertinggi yang dihasilkan oleh panel surya. Sebelumnya harus mencari fill factor atau faktor pengisi solar cell.

$$
\mathrm{FF}=\frac{17.8 \times 1.13}{21.8 \times 1.23}=0.75
$$

1. Efisiensi Arah Posisi Pemasangan Panel Surya Menghadap Timur

$$
\begin{gathered}
\eta=\frac{0.75 \times 1.34 \times 19.77}{1000 \times 0.17} \\
=\frac{19.86}{170}=0.116 \\
0.116 \times 100 \%=11.6 \%
\end{gathered}
$$

2. Efisiensi Arah Posisi Pemasangan Panel Surya Menghadap Selatan

$$
\begin{aligned}
& \eta=\frac{0.75 \times 0.41 \times 20.2}{1000 \times 0.17} \\
& =\frac{6.211}{170}=0.036
\end{aligned}
$$


JUST TI, Volume 11 Nomor 2, Juli 2019: 12-17

$$
0.036 \times 100 \%=3.6 \%
$$

3. Efisiensi Arah Posisi Pemasangan Panel Surya Menghadap Utara

$$
\begin{gathered}
\eta=\frac{0.75 \times 1.25 \times 19.7}{1000 \times 0.17} \\
=\frac{18.46}{170}=0.1085 \\
0.1085 \times 100 \%=10.85 \%
\end{gathered}
$$

\section{V.SIMPULAN}

Dari hasil pengujian panel surya $20 \mathrm{wp}$ dengan type Polycristaline maka penulis memberikan simpulan bahwa:

1. Arah posisi pemasangan panel surya sangat berpengaruh terhadap daya keluaran panel surya, panel surya yang menghadap timur dan utara sangat dominan dibandingkan posisi panel surya menghadap selatan.

2. intensitas cahaya matahari berpengaruh tehadap daya keluaran panel surya yaitu semakin besar intensitas cahaya matahari maka semakin besar pula daya keluaran yang dihasilkan oleh panel surya.

3. besar intensitas cahaya matahari terbesar ada pada arah posisi panel menghadap timur yaitu 595300 lux dan menghasilkan daya keluaran 23,80836 watt pada pukul 10.30 dan besar intensitas cahaya matahari pada arah posisi panel menghadap utara yaitu 244900 lux dan menghasilkan daya keluaran 24.625 watt pada pukul 12.30.

4. Kinerja panel surya terbaik bisa dilakukan pada pukul 10.30 sampai dengan 12.30 yang mana pada waktu tersebut panel surya sudah bisa menghasilkan daya yang tinggi untuk digunakan melayani beban tapi tetap harus memperhatikan faktor cuaca.

5. Efisiensi arah posisi pemasangan panel surya menghadap timur sebesar $11.6 \%$ dan efisiensi arah posisi pemasangan panel surya menghadap selatan sebesar 3.6\% dan efisensi arah posisi pemasangan panel surya mengahadap utara sebesar $10.85 \%$.

\section{Referensi}

[1] N. Azizi, "Cadangan minyak tak lagi melimpah momen tepat beralih ke energi baru terbarukan," Kementrian energi dan sumber daya mineral republik indonesia, 25 mei 2018. [Online]. Available: https://www.esdm.go.id/id/media-center/arsipberita/cadangan-minyak-tak-lagi-melimpah-momentepat-beralih-ke-energi-baru-terbarukan. [Accessed 24 Juli 2019].

[2] Indopos, "Energi listrik yang terjangkau untuk listrik berkeadilan," [Online].

[3] S. U. Putra, "Pemanfaatan energi matahari sebagai sumber energi alternatif," 6 Maret 2016. [Online]. Available:

http://suryautamaputra.co.id/blog/2016/03/06/pemanfaat an-energi-matahari/. [Accessed 24 Juli 2019].

[4] M. A. Saputra, M. F. Aziz, E. A. Sinuraya, N. A. Firdaus, R. N. Rafiandi and D. F. U. Putra, "Inovasi peningkatan efisiensi panel surya berbasis fresnel solar concentrator dan solar traker," pp. 1-6.

[5] H. Asy'ari, Jatmiko and Angga, "Intensitas cahaya matahari terhadap daya keluaran panel sel surya," Simposium nasional RAPI XI FT UMS, no. ISSN: 1412-9612, pp. 52-57, 2012.

[6] S. Pukhrem, "How solar cells work - components \& operation of solar cells," 13 Mei 2013. [Online]. Available: https://solarlove.org/how-solar-cells-workcomponents-operation-of-solar-cells/.

[7] M. Martawati, "Analisis simulasi pengaruh variasi intensitas cahaya terhadap daya dari panel surya," Jurnal ELTEK, vol 16 Nomor 01 , pp. 125-136, 2018.

[8] S. Yuliananda, G. Sarya and R. R. Hastijanti, "Pengauh perubahan intensitas matahari terhadap daya keluaran panel surya," jurnal pengabdian LPPM Untag Surabaya, vol. Vol. 01, no. No. 02, pp. 193-202, 2015.

[9] G. Knier, "How do photovoltaik work," 6 Agustus 2008. [Online]. Available: https://science.nasa.gov/sciencenews/science-at-nasa/2002/solarcells/.

[10] Janaloka, "cara kerja sel surya untuk produksi listrik bersih," 21 Februari 2017. [Online]. Available: https://janaloka.com/cara-kerja-sel-surya/.

[11] Janaloka, "Jenis-jenis panel surya yang telah digunakan di dunia," 28 Januari 2017. [Online]. Available: https://janaloka.com/jenis-jenis-panel-surya/.

[12] B. Yuwono, "Optimalisasi panel sel surya dengan menggunakan sistem pelacak berbasis mikrokontroler AT89C51," in Skipsi, Surakarta , Jurusan fisika fakultas matematika dan ilmu pengetahuan alam Universitas sebelas maret, 2005, p. 11.

[13] R. H. A. Prastica, Analisis pengaruh penambahan reflector terhadap tegangan keluaran modul solar cell, Surakarta : Teknik elektro universitas muhammadiyah, 2016.

[14] G. Raditya, "Efisiensi pada panel surya: apakah penting?," 25 juli 2017. [Online]. Available: https://janaloka.com/efisiensi-pada-panel-surya/.

[15] D. F. Rahmawati, "Sel Surya," in Elektrokimia Transformasi Energi Kimia-Listrik, Yogyakarta, Graha Ilmu, 2013, pp. 63-66. 
Shalih dan Suratno, Pengaruh Arah Posisi Pemasangan Panel Surya Terhadap Output Daya Keluaran

[16] A. Kusnandar, "Konversi Energi Photovoltaik," in Pengkajian Sumber Tenaga Listrik, Bandung, Arfino Raya, 2008, pp. 77-86.

[17] P. A. Kadir, "Konversi Energi Fotovoltaik," in Energi, Jakarta, Universitas Indonesia, 1990, p. 229.

[18] I. B. Ramadhani, M.Sc., Instalasi Listrik Tenaga Surya Dos \& Don'ts, Jakarta: Energising Development (EnDev) Indonesia, 2018. 